\title{
МОВОЗНАВСТВО
}

\section{ДОСЛІДЖЕННЯ ВІТАЛЬНОСТІ МАЛОПОШИРЕНИХ МОВ УКРАЇНИ: ДОСВІД І ПЕРСПЕКТИВИ}

\author{
ЛІЛІЯ АНДРІЕНКО \\ Інституту мовознавства ім. О.О. Потебні НАН України, Київ - Україна \\ lileja842@gmail.com; ORCID: 0000-0002-5113-6966
}

\section{BADANIE ŻYWOTNOŚCI MAŁO POWSZECHNYCH JĘZYKÓW UKRAINY: DOŚWIADCZENIA I PERSPEKTYWY}

\author{
LILIJA ANDRIJENKO \\ Instytutu Językoznawstwa im. O.O. Potebni Akademii Nauk Ukrainy, Kijów - Ukraina
}

STRESZCZENIE. Niniejsze badanie podsumowuje osiągnięcia ukraińskiej socjolingwistyki przełomu XX i XXI wieku w zakresie studiów nad językami mniejszości narodowych w Ukrainie. Aktualność owego badania wynika $\mathrm{z}$ oddziaływania nowego paradygmatu światopoglądowego, którego prymarną funkcją jest świadomość ekologiczna. Jej celem jest zachowanie i ochrona unikalnego dziedzictwa kulturowego ludzkości, któremu zagraża niwelacja lub zagłada. Tak duże zainteresowanie kwestią języków mniejszości narodowych jest związane również ze zmieniającym się kontekstem społeczno-politycznym w krajach postradzieckich, zwłaszcza w Ukrainie. Dlatego też istnieje pilna potrzeba socjolingwistycznego monitorowania sytuacji językowej, a także badania warunków oraz mechanizmów zachowania języków mniejszościowych w regionach dwujęzycznych i wielojęzycznych. Ważne jest również opracowanie praktycznych zaleceń dotyczących równoważenia praw językowych oraz potrzeb kulturowych społeczności etnolingwistycznych Ukrainy. Badanie zostało przeprowadzone w ramach projektu naukowego „Praktyki ochrony językowej europejskiego obszaru językowo-kulturowego oraz perspektywy polityki językowej na Ukrainie" (2019-2023). Stosowana w badaniu metoda opisu diachronicznego pozwala śledzić ewolucję poglądów badawczych, a także zmiany w metodycznych założeniach dotyczących problemów konstrukcji języka w Ukrainie od czasów ZSRR po dziś dzień.

Słowa kluczowe: języki Ukrainy, język państwowy, język zagrożony, wielojęzyczność, dwujęzyczność, diglossia, sytuacja językowa, polityka językowa, planowanie językowe, żywotność języka, wspólnoty etniczno-narodowe 


\title{
RESEARCHING OF VITALITY OF LESSER-USED LANGUAGES OF UKRAINE: EXPERIENCE AND PROSPECTIVES
}

\author{
LILIIA ANDRIIENKO \\ O.O. Potebnia Institute of Linguistics of the National Academy of Sciences of Ukraine, \\ Kyiv - Ukraine
}

\begin{abstract}
This study summarizes the achievements of Ukrainian sociolinguistics at the turn of the 21 st century in the field of studying the languages of national minorities in Ukraine. The relevance of the study lies in the influence of the new worldview paradigm. Its goal is to preserve and protect humanity's unique cultural heritage, which is under threat of reduction or destruction. The topicality of sociolinguistic studies of the languages of national minorities is also associated with the changing socio-political context in post-Soviet countries, especially in Ukraine. Consequently, there is a need for sociolinguistic monitoring of the linguistic situation, as well as for studying the conditions and mechanisms of linguistic behavior of minorities in bilingual and multilingual regions. It is also important to develop practical recommendations on the balance of linguistic rights and cultural needs of Ukrainian ethnolinguistic communities. The study is presented as part of the research project entitled "Practices of language protection of the European linguistic and cultural space and the prospects for language policy in Ukraine" (2019-2023). The method of diachronic description allows us to trace the evolution of research ideas and the changes in methodological premises regarding the problems of language evolution in Ukraine from the times of the USSR to the present day.
\end{abstract}

Keywords: languages of Ukraine, state language, endangered language, multilingualism, bilingualism, diglossia, language situation, language policy, language planning, language vitality, ethnic and national communities

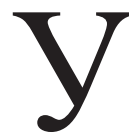

вага суспільства до проблем міноритарних мов та мов, які перебувають на межі зникання, значною мірою зумовлена впливом нових світоглядних моделей, котрі набувають усе більшого поширення й обгрунтованої ваги. ідеться про формування екологічної свідомості, в основі якої лежить розуміння нерозривної єдності, взаємозалежності різних вимірів людського буття: біологічного та цивілізаційного, універсального та унікального, новітнього та архаїчного, масового та елітарного, життєздатного й загроженого.

Дослідження, які розвиваються в руслі екологічного мислення, мають багато спільних позицій, котрі грунтуються на: 1) синкретизмі (насамперед, залученні здобутків і напрацювань різних галузей знань); 2) чітких ціннісних орієнтирах (ідеться про усвідомлене й уважне ставлення до різноманіття духовних і культурних надбань людства); дестинативності (націленості на результат, який матиме прикладне значення). Запропонована модель може бути успішно використана й для сучасних соціолінгвістичних досліджень, для яких завжди була актуальною проблема функціонування й розвитку мов 
у бі- або полілінгвальному мовному середовищі, їхнього правового та комунікативного статусу, вітальності.

Питання багатомовності як невід'ємного атрибута мовної ситуації в Україні має тривалу “історію”, яка грунтується як на цілком реальних фактах, так і на низці ідеологем та міфологем. Одна з них - теза про поліетнічність та полікультурність України, що, на нашу думку, $є$ продовженням радянського підходу, який впроваджував ідеологічно заангажований статусний розподіл мов у багатонаціональній державі. Згідно з офіційною доктриною, це були: мова міжнаціонального спілкування, російська, та національні мови, під якими розуміли мову автохтонного населення, тобто мову більшості в національних республіках і мови корінних народів, які становлять меншість у цих республіках, сюди ж відносили мови “трудових мігрантів” (запрошених фахівців, випускників вишів) з інших республік Радянського Союзу. Термін державна мова у Радянському Союзі мав трохи не табуйований характер: "В нашій країні (СРСР - Л. Андрієнко) немає єдиної державної мови. Разом з тим швидке зростання міжнаціональних зв’ язків веде до підвищення значення російської мови - вона стала засобом спілкування всіх націй і народностей СРСР" [Розвиток мовознавства в УРСР 1980: 23].

Дистрибуція мов у соціально-комунікативній системі “багатонаціонального мовного колективу” Радянського Союзу, і Радянської України зокрема, яка грунтувалася на принципах функціонального доповнення, не враховувала інтересів тих мовців, мови яких нездатні були витримати конкуренцію в умовах диглосії, коли "відповідно до потреб суспільства різні мови, які функціонують в межах певного мовного колективу, використовують у різних комунікативних сферах, або ж з різним функціональним навантаженням у певній сфері, і таким чином, взаємно доповнюють одна одну у функціональному плані” [Словарь социолингвистических терминов 2006: 62]. Це, хоч і не прямо, спричиняло до того, що поза увагою суспільства залишалися питання підтримки й захисту мов із ослабленою комунікативною потужністю, а повсюдно впроваджувана формула “двох рідних мов” поступово переводила їх у ранг “мови для домашнього вжитку”. Більше того, така доля найчастіше випадала справді рідній (материнській, успадкованій) мові та була вготована мажоритарним мовам республік, кожна 3 яких мала декларативний статус мови офіційно-ділового спілкування й освіти, що не завжди гарантувало сприятливі умови для іiї розвитку.

Формально-правовий аспект мовної політики СРСР не відповідав реальній політичній практиці: адже за позірно ліберальними підходами та гарантіями забезпечувати “гармонійний розвиток” усіх мов та вільний вибір мови спілкування, було приховано намір на поступове витіснення національних мов з ужитку, заміщення їх російською як мовою міжнаціонального спілкування. Наукова дискусія щодо мовного будівнищтва мала обмежений ідеологічним 
регламентом характер, через що більшість соціолінгвістичних праць аж до к. XX ст. зосереджувалися довкола проблем українсько-російської двомовності, а “ширина" й "глибина" таких розмислів апріорі не могла сягнути за межі готових приписів та офіційних догм.

Тема українсько-російської двомовності У вітчизняному мовознавстві й досі є однією із найбільш актуальних і обговорюваних, позаяк прогалини в цій ділянці та низка нерозв'язаних проблем соціолінгвістичного характеру потребують від науковців значних зусиль для об'єктивного опису та аналізу ситуації, що має тривалу історію [Радевич-Винницький 2011: 32-61]. Попри політичну цензуру й ідеологічний тиск українські лінгвісти розробили низку теоретичних положень щодо функціонування мов у багатомовних континуумах, зокрема на прикладах мовно-національних відносин інших держав.

Олександр Мельничук виокремив три основні суспільно-функціональні типи мов: мова міжначіонального спілкування, яка одночасно є мовою однієї із націй цієї держави або мовою іноземної нації, національні мови або мови народностей, які мають писемність і перебувають у відношеннях функціональної дистрибуції, та безписемні мови й діалекти малочисельних етнічних груп, що не мають статусу літературних [Мельничук 1970: 13]. Саме така модель статусного ранжування мов імпліцитно впроваджувалася в тогочасному мовному менеджменті всього Радянського Союзу й мовному будівництві його окремих республік.

Аналіз мовних ситуацій та досвід мовного будівництва інших країн давав змогу українським ученим, які вимушено перебували за “залізною завісою”, залучати до наукового обігу праці зарубіжних лінгвістів, популяризувати нові ідеї, і це мало, безумовно, прогресивний характер [Питання теорії мови в зарубіжному мовознавстві 1976]. Важливими кроками, які сприяли розширенню наукових обріїв у галузі соціолінгвістики, стали переклади, хоч і з деякими купюрами, відомих праць зарубіжних лінгвістів. У 1979 році в Києві в перекладі Юрія Жлуктенка вийшла книга У. Вайнраха Мовні контакти. Стан i проблеми дослідження (Языковые контакты Состояние и проблемы исследования). У цій праці чи не вперше було порушено питання про джерела мовної лояльності та мовної стійкості; висловлено міркування щодо мов, які потребують захисту в контексті мовної ситуації, що склалася в умовах бі- або мультилінгвізму [Вайнрах 1979: 166]. Ці ідеї знайшли творчий розвиток у працях Ю. Жлуктенка, Б. Ажнюка, Г. Яворської, Л. Лазаренко, О. Чередниченка та багатьох інших українських мовознавців.

Задля справедливості треба відзначити, що мови окремих етнічних груп та компактних мовних колективів України не випадали з поля зору українських учених. Активно розвивалася унгаристика, романістика, полоністика, болгаристика, юдаїстика, неоелліністика. Серед пріоритетних напрямів досліджень були проблеми міжмовних контактів в умовах дво- та багатомовності, 
вивчення особливостей внутрішньоструктурних змін, які виникли внаслідок цих контактів.

Завдання власне соціолінгвістичних досліджень мов України було покладено на створений в грудні 1991 року в Інституті мовознавства ім. О.О. Потебні НАНУ Відділу мов України на чолі з Орестом Ткаченком, який визначив завдання нового наукового підрозділу так: “. ...Поряд із вивченням суто науково-теоретичних проблем, що не могло бути його єдиним призначенням, відділ своєю науково-популяризаційною та дорадчо-рекомендаційною роботою міг і мав сприяти встановленню гармонійних міжмовних і міжетнічних стосунків між усіма етносами України" [Ткаченко 2005: 293].

Актуальність і важливість таких настанов була продиктована самим життям. Адже проголошення незалежності в 1991 році, утвердження України як самостійної суверенної держави сприяли пробудженню національної свідомості українців та етнополітичному відродженню національних меншин України, які почали активно долучатися до процесу державотворення, впливати на формування офіційної політики в сфері етнонаціональних відносин, включно із питаннями мовного планування та захисту мовних прав.

Сфера мовного менеджменту перших років пострадянської доби потребувала системних реформ, що враховували б переформатування комунікативного простору і нову, ціннісно-світоглядну парадигму, у якій збалансовано інтереси українців як домінантного етносу та мовно-культурні запити всіх етнонаціональних спільнот України. На порядку денному постали такі питання: по-перше, про зміну статусу російської етнічної групи населення та iii трансформації у національну меншину з відповідними політико-правовими статусними нормами, притаманними такому типу етнічних спільнот; no-друге, формування "інституційної наповненості" в середовищі тих етнонаціональних спільнот, які не могли зберігати свою ідентичність через розпорошеність чи невизначений статус, як-то “інші етноси”. До таких зараховували кримськотатарську спільноту, гагаузів, кримчаків, караїмів, ромів, урумів та румеїв. У цей період (90-і pp. ХХ ст.) в Україні прийнято низку законодавчих актів, які визначили правові засади розвитку національних меншин:“Про національні меншини в Україні” (1992р.), "Про ратифікацію Рамкової конвенції про захист меншин в Україні”, (1997р.), "Про ратифікацію Європейської хартії регіональних мов або мов меншин” (2003 р.).

Попри суперечливий характер Європейської хартії регіональних мов або мов меншин (далі Хартіï) та іiї перекладів, попри намагання окремих політичних сил використати ії як інструмент задля збереження панівного статусу російської мови, ратифікація цього документа мала для України історичне значення. Воно насамперед полягало в тому, що українське суспільство виявило готовність працювати в системі координат, заданій Європейським співтовариством, прийнявши його базові цінності “задля втілення в життя ідеалів 
і принципів, які є їхнім спільним надбанням, зокрема в збереженні та розвитку культурного багатства і традицій Європи" [Європейська хартія: Преамбула]. До того ж, Хартія стала тим документом, у якому було окреслено коло присутніх та теренах України мов, які потребують державної підтримки. Таким чином було проведено межу між мовами етнонаціональних спільнот України: міноритарними й регіональними (це "мови, які традиційно використовуються у межах певної території громадянами цієї країни, які сформувалися з груп, що менші за чисельністю від решти населення цієї країни та їхня мова відрізняється від офіційної (державної) мови цієї країни") [Європейська хартія], мовами мігрантів (зокрема, мовців, якими $є$ вихідці із країн СРСР) та державною мовою з усім ії діалектним розмаїттям.

Реєстр міноритарних мов було сформовано на основі принципів історизму та традиційності (культурної тяглості) й за кількісним критерієм, які мають вибірковий характер, що не суперечить положенням Хартіï. На жаль, при формуванні цього реєстру не було приділено належної уваги вивченню світового досвіду щодо визначення рівня загроженості мов, що в подальшому унеможливило конструювання об'єктивних та суб'єктивних параметрів вітальності цих мов.

Із роботи над перекладами Хартії та ії термінологічним апаратом було також винесено важливі уроки щодо того, як двояке прочитання термінів у текстах мовного законодавства може стати причиною різнотлумачень нормативних документів, що регулюють мовну практику; як ці різнотлумачення можуть бути використані в маніпулятивних технологіях в умовах гібридної війни, і як усе це в цілому негативно впливає на конструювання концептуальних засад мовної політики держави. Богдан Ажнюк слушно відзначив:

Термінологічні інновації в багатьох слов’янських мовах виникли під впливом „Європейської хартії регіональних або міноритарних мов”. Аналіз показує, що термін, який є адекватним у контексті акта міжнародного права (наприклад, регіональна або міноритарна мова), може бути не цілком придатним для термінологічної та концептуальної системи національного законодавства (наприклад, України). Ця розбіжність спричиняє численні суперечності теоретичного плану та викликає труднощі при застосуванні закону на практиці [Ажнюк 2013: 163].

Отже, одним із найважливіших завдань сучасної соціолінгвістики є кодифікація термінологічної лексики та якомога повнішого відображення в спеціалізованих соціолінгвістичних енциклопедіях і словниках іiї понятійно-термінологічного апарату.

Наукова дискусія, спричинена різними версіями перекладу Європейської хартії регіональних мов або мов меншин щодо тлумачення термінопонять “регіональна мова", “мова меншини” чи “меншинна мова”, “міноритарна мова", “загрожена мова" певним чином підготовала теоретичний грунт для 
подальшого кваліфікованого лінгвоюридичного супроводу виконання зобов’язань Хартії, що його нині успішно здійснює в складі робочої групи завідувач відновленого в 2009 р. Відділу мов України в Інституті мовознавства ім. О.О. Потебні, а нині директор цього інституту проф. Б. Ажнюк. Відділ мов України став організатором низки міжнародних конференцій та круглих столів, присвячених цій актуальній проблематиці, що відкрило простір для фахового обговорення й підготовки теоретичної бази в галузі соціолінгвістичного менеджменту, мовного законодавства, мовної екології, мовних прав, юридичної лінгвістики і лінгвістичної експертології; а також розробки прикладних аспектів ефективного впровадження мовного планування в оновленому форматі. За матеріалами конференцій було видано збірники наукових праць: Екологія мови і мовна політика в сучасному суспільстві (2012 р.); Мовні права в сучасному світі (2014р.); Мовне законодавство і мовна політика: Україна, Свропа, світ (2019 р.). Важливою подією стала також міжнародна наукова конференція “Загрожені мови: кримськотатарська та інші тюркські мови в Україні” під егідою Інституту сходознавства ім. А.Ю. Кримського НАН України (Київ, 2014 р.). За матеріалами конференції було укладено збірник наукових праць, який, за словами організаторів, “...становить першу в Україні спробу предметного звернення до проблематики загрожених мов взагалі і ситуації з тюркськими мовами в Україні зокрема" [Загрожені мови 2016: 4]. I таких наукових подій, які з погляду прагматики є дуже результативними, відбувається в Україні чимдалі більше.

Кожен наступний крок наукового прогнозування чи планування має виходити із реального стану речей, тобто враховувати поточну мовну ситуацію та суспільні настрої, які відображають, на жаль, певну інертність мовців, їхню нездатність подолати психологічно-рольові бар'єри та усталені стереотипи. Через це в українському суспільстві ще не знайдено універсальної формули, здатної, гармонізувати мовно-культурний простір України, аби урівноважити інтереси всіх їі етномовних спільнот. Зокрема, уважати на інтереси російської етноспільноти, якій важко дається усвідомлення втрати престижу російської мови; урахувати запити представників національних меншин, котрі у своєму вимушеному білінгвізмі не готові російську мову змінити на українську i, найголовніше, - вплинути на ставлення до рідної мови представників загрожених мов, які в умовах жорсткого прагматизму нерідко самі відмовляються від своєї мови.

I якщо останнім часом спостерігаємо певну позитивну динаміку щодо двох перших позицій (ідеться про поступову заміну національно-російського білінгвізму національно-українським, напр., румунсько-українським, кримськотатарсько-українським, про що свідчать опитування, які проводять громадські організації, соціологічні служби тощо), то вузол проблем щодо загрожених мов є тугим і дуже заплутаним. Робота із ревіталізації загрожених 
мов потребує комплексного підходу, який включає академічний компонент (документування та опис мов), законодавчо-адміністративний (державний протекціонізм, видання книжок та періодичної літератури, освітні програми, підготовка підручників), і найголовніше - просвітницький. Важливо донести до мовця, який робить вибір на користь тієї чи тієї мови, вагається, якої мови навчати дітей чи внуків, що його мова дуже важлива, і не лише в масштабах особистості, родини, пам'яті роду, донести, що ця мова є великим дарунком людству, світовій культурі, і від кожної людини персонально залежить, чи світ отримає цей дарунок, чи втратить назавжди.

Отже, українська соціолінгвістика пройшла непростий шлях становлення, у якому були й “темні місця”, і значні наукові здобутки. На жаль, суспільно-політична атмосфера тоталітарної держави не сприяла вільній науковій дискусії та всіляко гальмувала ініціативи щодо перегляду важливих аспектів мовно-культурного розвитку етнічних спільнот України, підпорядковуючи сферу “мовного будівництва" визначеній політичній меті. У пропонованій моделі не було місця для меншинних та загрожених мов. Натомість “вільний розвиток” мов усіх народів Радянського Союзу закінчувався там, де поставало питання статусної ієрархії та розмежування функцій різних мов у багатонаціональній державі. До того ж, увага до мов національних меншин порушували низку “незручних” соціально-політичних проблем, які виходили далеко за межі суто мовознавчої дисципліни, а саме, депортація корінних народів, асиміляція, русифікація, лінгвоцид.

Уважне й критичне прочитання праць, створених у попередній період, є необхідним і вкрай важливим, оскільки спонукає до пошуку виважених, науково обгрунтованих підходів до досліджень у цій галузі. Тож перед сучасною соціолінгвістикою стоїть низка теоретичних і прикладних завдань. По-перше, постійний моніторинг та об'єктивне висвітлення поточної мовної ситуації в Україні з урахуванням історичного контексту, особливо в регіонах компактного проживання етномовних спільнот і на порубіжних теренах. По-друге, кодифікація соціолінгвістичної термінології, їі відображення в спеціалізованих лексикографічних джерелах задля формування надійного теоретичного підгрунтя лінгвоекспертної та лінгвоюридичної діяльності в галузі мовного законодавства і мовної політики. По-третє, “розгерметизація” академічної науки про мову, що передбачає залучення лінгвістів до активного обговорення мовно-культурних та мовно-правових аспектів життя українського суспільства. Реалізація цих наукових проєктів збагатить українську соціолінгвістику новими теоретичними здобутками, сприятиме вдосконаленню лінгвоюридичного інструментарію в галузі мовного менеджменту й матиме позитивний вплив на гармонізацію мовних відносин в Україні. 


\section{Список використаної літератури}

Ажнюк Б.М., Сучасні тендениї̈ в розвитку слов 'янської соиіолінгвістичної термінології (статус мов), [в:] „Мовознавство”, 2013, № 2-3, с. 163-183.

Вайнрайх У., Языковые контакты. Состояние и проблемы исследования, Київ: Вища школа, 1979.

Екологія мови і мовна політика в сучасному суспільстві, Київ: Видавничий дім Д. Бураго, 2012.

Європейська хартія регіональних мов або мов мениин, [в:] Електронний ресурс: https:// zakon.rada.gov.ua/laws/show/994_014\#Text (30.10.2020).

Євтух В.Б., Трощинський В.П., Етнонаціональна структура сучасного украӥнського суспільства: деякі аспекти системного бачення ї̈ розвитку, [в:] „Етнонаціональна структура українського суспільства: Довідник”, Київ: Наукова думка, 2004, с. 3-47.

Закон України „Про національні меншини в Україні”, [в:] Електронный ресурс: https:// zakon.rada.gov.ua/laws/show/2494-12\#Text (30.10.2020).

Лазаренко Л., Досвід мовних політик світу й украӥнська перспектива (інформаційно-аналітичний огляд), [в:] „Українська мова”, 2003, № 4, с. 3-22.

Мельничук О.С., Сучасні проблеми марксистсько-ленінського розуміння розвитку і взаємодії мов світу, [в:] „Мовознавство”, 1970, № 3, с. 3-17.

Мовне законодавство і мовна політика: Україна, Європа, світ, Київ: Видавничий дім Д. Бураго, 2019.

Мовний баланс України, упор. О. Медведєв, [в:] „Сучасність”, 2007, № 9, с. 69-89.

Мовні права в сучасному світі, Ужгород 2014.

Питання теорії мови в зарубіжному мовознавстві, Київ: Наукова думка, 1976.

Радевич-Винницький Я.К., Двомовність в Україні: теорія, історія, мововживання, Київ-Дрогобич: Посвіт, 2011.

Розвиток мовознавства в УРСР 1967-1977, Київ: Наукова думка, 1980.

Словарь соииолингвистических терминов, Москва 2006, [в:] Електронный ресурс: //http:// www.iling-ran.ru/library/sociolingva/slovar/sociolinguistics_dictionary.pdf (30.10.2020).

Ткаченко О.Б., Дослідження мов Украӥни, [в:] „Інститут мовознавства ім. О.О. Потебні НАН України: 1930-2005. Матеріали до історії', Київ: Наукова думка, 2005, c. $293-297$.

Яворська Г., Загрожені мови на ураженій мапі, [в:] „Загрожені мови. Кримськотатарська та інші тюркські мови в Україні”, Київ 2016.

\section{Spysok vykorystanoi literatury [References]}

Azhniuk B.M., Suchasni tendentsii v rozvytku slovianskoi sotsiolinhvistychnoi terminolohii (status mov) [Current trends in the development of Slavic sociolinguistic terminology (status of languages)], [v:] „Movoznavstvo”, 2013, nr 2-3, s. 163-183. 
Vajnrajx U., Yazykovye kontakty. Sostoyanie i problemy issledovaniya [Languages in Contact Findings and problems], Kiïv: Vishha shkola, 1979.

Ekolohiia movy i movna polityka $v$ suchasnomu suspilstvi [Ecology of language and language policy in modern society], Kyiv: Vydavnychyi dim D. Buraho, 2012.

Yevropeiska khartiia rehionalnykh mov abo mov menshyn [European Charter for Regional or Minority Languages], [v:] Elektronnyi resurs: https://zakon.rada.gov.ua/laws/ show/994_014\#Text (30.10.2020).

Yevtukh V.B., Troshchynskyi V.P., Etnonatsionalna struktura suchasnoho ukrainskoho suspilstva: deiaki aspekty systemnoho bachennia yii rozvytku [Structure of the Contemporary Ukrainian Society: Several Aspects of the Systematic Analysis of its Development], [v:] „Etnonatsionalna struktura ukrainskoho suspilstva: Dovidnyk”, Kyiv: Naukova dumka, 2004, s. 3-47.

Zakon Ukrainy ,, Pro natsionalni menshyny v Ukraini” [Law of Ukraine “On National Minorities in Ukraine"], [v:] Elektronnyi resurs: https://zakon.rada.gov.ua/laws/show/2494-12\#Text (30.10.2020).

Lazarenko L., Dosvid movnykh polityk svitu y ukrainska perspektyva (informatsiino-analitychnyi ohliad) [Experience of world language policies and Ukrainian perspective (informationanalytical review)], [v:] „Ukrainska mova”, 2003, nr 4, s. 3-22.

Melnychuk O.S., Suchasni problemy marksystsko-leninskoho rozuminnia rozvytku i vzaiemodii mov svitu [Modern problems of Marxist-Leninist understanding of the development and interaction of languages of the world], [v:] „Movoznavstvo”, 1970, nr 3, s. 3-17.

Movne zakonodavstvo i movna polityka: Ukraina, Yevropa, svit [Language legislation and language policy: Ukraine, Europe, the world], Kyiv: Vydavnychyi dim D. Buraho, 2019.

Movnyi balans Ukrainy [Language balance of Ukraine], upor. O. Medvediev, [v:] „Suchasnist”, 2007, nr 9, s. 69-89.

Movni prava v suchasnomu sviti [Language rights in the modern world], Uzhhorod 2014.

Pytannia teorii movy $v$ zarubizhnomu movoznavstvi [Questions of language theory in foreign linguistics], Kyiv: Naukova dumka, 1976.

Radevych-Vynnytskyi Ya.K., Dvomovnist v Ukraini: teoriia, istoriia, movovzhyvannia [Bilingualism in Ukraine: theory, history, language use], Kyiv-Drohobych: Posvit, 2011.

Rozvytok movoznavstva v URSR 1967-1977 [Development of linguistics in the USSR 19671977], Kyiv: Naukova dumka, 1980.

Slovar'sociolingvisticheskix terminov [Dictionary of Sociolinguistic Terms], Moskva 2006, [v:] Elektronnyj resurs: //http://www.iling-ran.ru/library/sociolingva/slovar/sociolinguistics dictionary.pdf (30.10.2020).

Tkachenko O.B., Doslidzhennia mov Ukrainy [Research of Ukrainian languages], [v:] „Instytut movoznavstva im. O.O. Potebni NAN Ukrainy: 1930-2005. Materialy do istorii”, Kyiv: Naukova dumka, 2005, s. 293-297.

Yavorska H., Zahrozheni movy na urazhenii mapi [Endangered languages on the affected map], [v:] „Zahrozheni movy. Krymskotatarska ta inshi tiurkski movy v Ukraini”, Kyiv 2016. 